\title{
一般演题 11
}

\section{八ローセン気化器に関する研究}

\section{(Halothane)}

Halothane は現在最も広く使われている麻酔 剂でありますが，麻酔力が強く，しかも常温で 高い蒸気圧を持っていますので正確な定量気化 器なしに Halothane 麻醉を行ならことは多く の危険を伴います．そこで，現在市販されてい る Halothane気化器のらち入手し得た 5 器種に ついてその構造および性能を検討しました. Halothane 濃度の測定は, gas sampler を接続 した gaschromatography を用い, 液温測定は thermistor 温度計を用いた. 定量型気化器の原 理は, 気化器の inlet から outlet 一直接流れる Bypass 側と, inlet から気化室に入いる側の流 量比で出口濃度を制御する仕組みで，気化室側 の gas は燈芯により，ほぼ飽和された蒸気が気 化器出口の Bimetallic valve で温度補償されて 出口濃度を規定しています.このような気化器 についてその特性を調べ, 次のごとき結果を得 ました。

1. 正確性 設定\%に対し， $\pm 0.1 \%$ 以内之 IOC で規定されていますが，特に使用 2 年以上の Fluotec MK-II 5 台の平均を取ってみたとこ ろ，図1のごとく設定\%に対し，0.1 0.5\% 低い值であった。

2. 方向特異性 本来の inlet $と$ outlet を逆連 結して carrier gas を通じた場合で，英国製 の Fluotec, ドイツ製の Vapor, 国産アコマ の Acomatec, 五十嵐の Fluoretta，市河思誠 堂の Halomatic の計 5 種について分析した. その結果, Fluotec, Acomatec, Fluoretta は 高濃度となるが，これは gas 流量比が異な り，かつ温度補償が無効となるためである.

*山口大学医学部麻酔学教室
石川 敏 三* 奥 田 佳 朗*
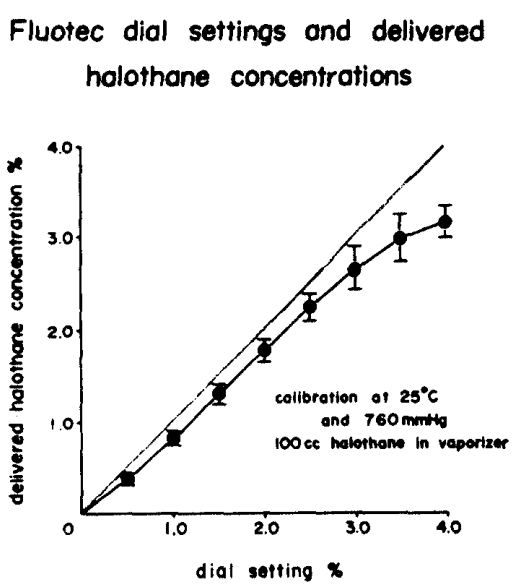

図 1

Vapor はほとんど変化なく，また Halomatic では高設定\%で低濃度となる。

3. 温度補傥 Acomatec において, それを恒温 槽に入れ, 温度を $10^{\circ} \mathrm{C}$ から $35^{\circ} \mathrm{C}$ まで50分間で 直線的に上昇させた時, 気化器出口濃度がど のように影響されるかをみた. 図 2 に示す。

Dial 設定 1.0〜0.5\%において, $15 \sim 30^{\circ} \mathrm{C}$ の 範囲で Bimetallic valveにより，良く制御さ れている.また，この時の気化室液温は恒温 槽温度より常に $0 \sim 2{ }^{\circ} \mathrm{C}$ 低く, 材質および構造

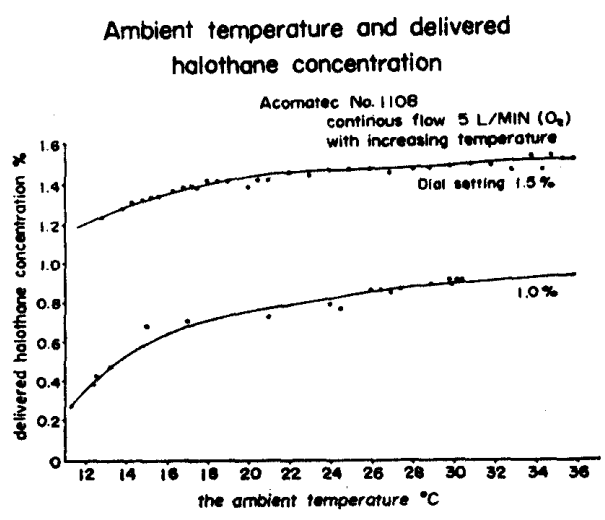

图 2 


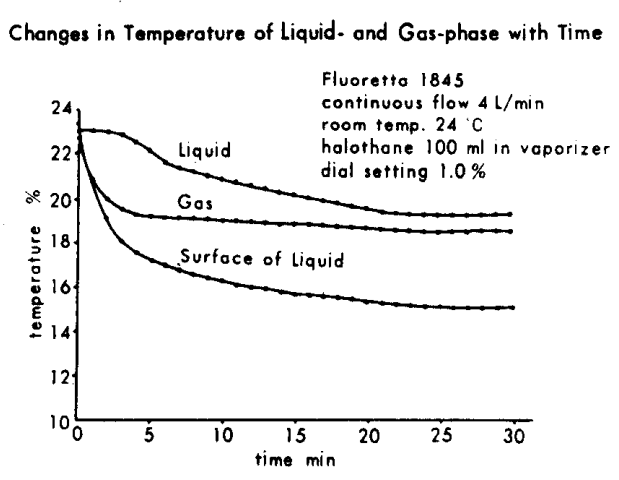

图 3

の熱伝導は充分であった.（温度較差が生じ なかった）次に気化潜熱による温度低下の様 子を図 3 に示す. 液相, 液表面, 気相の各温 度を gas を通じて測定したところ，気相温度 は速やかに平衡に達するが，気化潜熱により 液表面温度が急激に低下するため，液温が次 第に低下し, その後平衡に達する現象を示し たものである.これは gas 流量の多い程著明 でした. Bimetallic valve は気相部にあり， この温度によって気流分配率を変え制御して いる.また，この液温の低下は高流量・高設 定\%において濃度低下が起こる原因の1つで ある。

4. 異なる流量を通じたとき 各器種で特徵が あり, Fluotec MK-II と Fluoretta が類似し, 低流量で高濃度となる。これは， Bypass 側 よりも気化室側に低流量では gas が入り易 い構造のためである。 また，Acomatec と Halomatic が類似し，低流量で低濃度とな る. Vaporにおいては, $0.1 \sim 10 \mathrm{l} / \mathrm{min}$ の範 囲で安定であるという報告がある.

5. $\mathrm{N}_{2} \mathrm{O}$ gas 使用のとき $\mathrm{N}_{2} \mathrm{O}$ gas carrier gas に用いた時の様子を図 4 に示す. 純 $\mathrm{N}_{2} \mathrm{O}$ を $4,6,8 \mathrm{l} / \mathrm{min}$ で通じ，同様に $\mathrm{O}_{2}$ を通じた

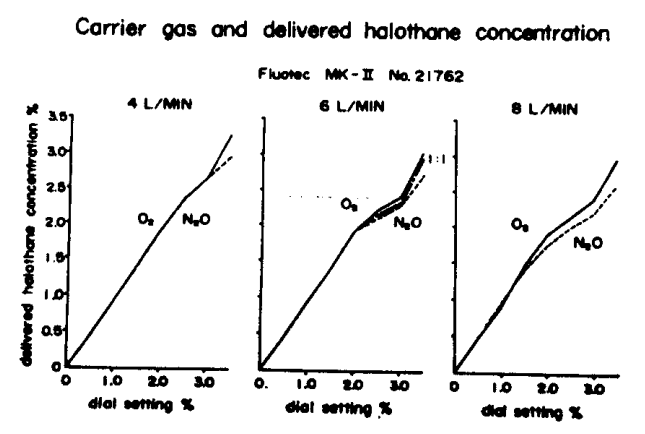

图 4
場合のそれぞれの漸度で， $\mathrm{O}_{2}$ は実線， $\mathrm{N}_{2} \mathrm{O}$ は破線です。これから 6 8l/min の高設定\% で濃度低下があるが，臨床使用における $\mathrm{O}_{2}$ と $\mathrm{N}_{2} \mathrm{O} 1: 1$ 総流量 $6 l / \mathrm{min}$ では中央のグラ フのごとく， $\mathrm{O}_{2}, \mathrm{~N}_{2} \mathrm{O}$ の中間に位置し，使用 には殆んど差支えない。

6. 燈芯および燈芯による気化効率 気化効率 を最大限にするための重要な因子は燈芯で,

Wick Moterial and Efficiency of Voprization

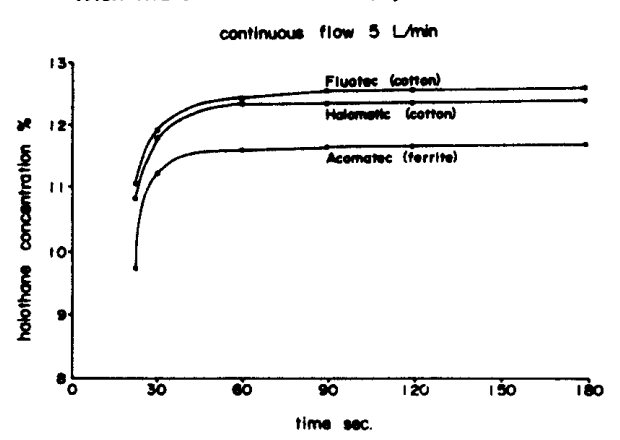

図 5

その条件としては, capillary効果がある程度 良く，接触面積の広いこと，また耐薬品性お よび経済的なことが挙げられる。図 5 は, Halothane を入れたフラスコに同一面積の登 芯を入れ，定常なgasを通じた時のフラスコは 内濃度である.これから Fluotec の木綿製燈 芯は capillary 効果が多少 Acomatec の ferrite 製燈芯より悪いが飽和濃度が高いので，より 効果的である. Halomatic の木綿製燈芯は Fluotec それより, 織目が荒いため少し低く なっている.

また, 図 6 液温からの飽和蒸気圧と気化 室側からの Halothane 実測濃度とで, 蒸気の 飽和度を求めたものである。方法は，まず

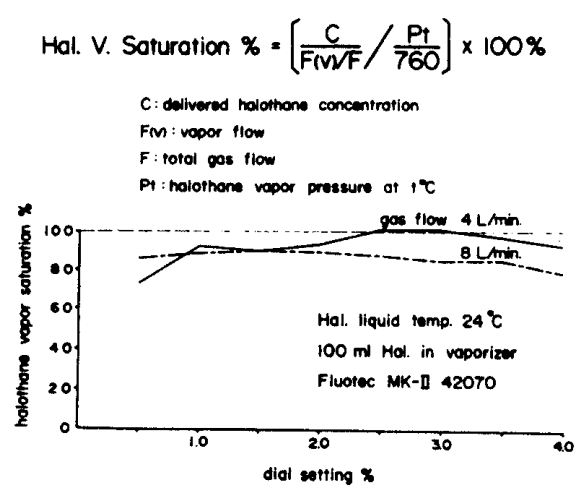

図 6 
Bypass 側と気化室側の流量を測定し, 気化室 流量を全流量で割った值を求め，その時の出

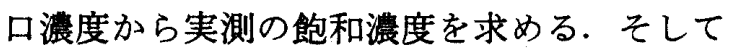
液温から飽和蒸気圧濃度が分かり, この比を 求めると蒸気飽和度が算出できます. (図 6 の 上の式です.）また，グラフは横軸に設定\% を, 縌軸に蒸気飽和度を取ってある. 実線が $4 l / \mathrm{min}, 1$ 点鎖線が $8 l / \mathrm{min}$ を示す. これか ら, $4 \mathrm{l} / \mathrm{min}$ で平均 $92.5 \%$ 飽和, $8 \mathrm{l} / \mathrm{min}$ では 平均 $86.3 \%$ 飽和であった. $8 \mathrm{l} / \mathrm{min}$ で多少低 下するのは，気化潜熱扔よび分子運動が激し いために気液平衡に達し得ないためである.

7. 各気化器の比較 以上のことを考虑しなが ら燈芯型定量気化器 5 種について, 流路およ び構造的観点での特長を比較した. 特に, Vapor は本体に高熱伝導性の銅を用い，蒸気 圧を考慮した補正曲線に Dial を合わし，補 償を行なうもので今までの気化器では最も正
確なものといわれ，Halothane Analyzer の calibration に用いられることもあります。

以上，述べてきたことを要約すると，

1. 方向特異性は各器種で異なる

2. $\mathrm{N}_{2} \mathrm{O}$ gas 使用では高流量・高設定\%で濃 度は低下する。

3. 外気温と気化器内液温との差は $2^{\circ} \mathrm{C}$ 以内 である。

4. 出口濃度は $15 \sim 30^{\circ} \mathrm{C}$ で良く制御されてい る.

5. 気化室からの蒸気は gas 流量 $4 l / \mathrm{min}$ で 平均 $92.5 \%$ 飽和, $8 \mathrm{l} / \mathrm{min}$ では $86.3 \%$ 飽 和であった。

6. 5 種の比較をした.

麻酔刀の強い Halothane を安全に使用する ためには, 気化器の構造と性能を充分知ってお く必要がある。 